\title{
Higher failure of female older asthma patients in use of inhalants: is it due to older age and/or cognition problems?
}

This article was published in the following Dove Press journal:

Clinical Interventions in Aging

27 November 2015

Number of times this article has been viewed

\author{
Ozlem Soyluk' \\ Gulistan Bahat ${ }^{2}$ \\ 'Division of Endocrinology and \\ Metabolism, ${ }^{2}$ Division of Geriatrics, \\ Department of Internal Medicine, \\ Istanbul Medical School, Istanbul \\ University, Capa, Istanbul, Turkey
}

Correspondence: Ozlem Soyluk Division of Endocrinology and Metabolism, Department of Internal Medicine, Istanbul Medical School, Istanbul University, Millet cad., Capa, 34390 Istanbul, Turkey $\mathrm{Tel}+902124142000$ ext 33204 Fax +90 212 5324208

Email drozlem76@hotmail.com

\section{Dear editor}

We read the article entitled "Sex differences in use of inhalants by elderly patients with asthma" by Hirose et al with interest. ${ }^{1}$ In this study, the authors examined the relationship between inhalation procedure and sex difference in elderly patients with asthma. They reported that females failed more in "breath holding". Therefore, they suggested that elderly female patients with asthma have less understanding of inhaled steroid therapy and thus it is particularly important to confirm that the correct inhalation procedure is used by elderly female patients with asthma.

We would like to comment on their article with some points. It is reported that the patients included 66 males and 89 females with mean ages of $75.5 \pm 5.65$ vs $78.7 \pm 6.87$ years, respectively, who did not have dementia, neurological disorders, or muscular disorders. Obviously, the female patients were older than the male patients while there is no information whether this is statistically significant or not. The authors already noted that inhalation therapy may be difficult to administer in aged patients - stressing the age itself as an important factor for appropriate inhalation. We would like to ask whether the age difference between the male and female subjects was analyzed statistically.

The other point is that they reported as they excluded the subjects with dementia, neurological disorders, or muscular disorders. Although the diagnoses of muscular and most neurological disorders that might affect inhalation are generally straightforward and recognizable by history and/or physical examination, diagnosis of dementia is easily dismissed as it can mistakenly be considered as part of the normal aging process. ${ }^{2}$ We would like to ask the methodology they used to exclude dementia - ie, if they performed any screening to exclude dementia or judged only by review of current prespecified diagnoses. We suggest that as age and female sex are very well-known risk factors for Alzheimer's dementia, ${ }^{3}$ the more common failure of the female sex in "breath holding" may be due to higher prevalence of cognitive disorders in this older-female patient group.

\section{Disclosure}

The authors report no conflicts of interest in this communication. 


\section{References}

1. Hirose M, Kondo R, Ban N, Kuwabara K, Shiga M, Horiguchi T. Sex differences in use of inhalants by elderly patients with asthma. Clin Interv Aging. 2015;10:1305-1310.

2. Fleming KC, Adams AC, Petersen RC. Dementia: diagnosis and evaluation. Mayo Clin Proc. 1995;70(11):1093-1107.
3. Launer LJ, Andersen K, Dewey ME, et al. Rates and risk factors for dementia and Alzheimer's disease: results from EURODEM pooled analyses. EURODEM Incidence Research Group and Work Groups. European Studies of Dementia. Neurology. 1999;52(1):78-84. 


\section{Author's reply \\ Masahiro Hirose}

Department of Respiratory Medicine II, Fujita Health University School of Medicine, Nagoya, Japan

Correspondence: Masahiro Hirose

Department of Respiratory Medicine II, Fujita Health University School of Medicine, 3-6-10, Otobashi, Nakagawa-ku, Nagoya 454-85-09, Japan Fax +8I 523235675

Email hiromasa87@yahoo.co.jp

\section{Dear editor}

You commented on the possibility of a statistically significant difference in age between the male and female groups. The mean life expectancy of the Japanese population is higher than that of people in other countries, and the percentage of elderly people who remain active is high in Japan. While drafting the manuscript, we included statistical parameters only, and forgot to state the results of the analysis of individual parameters, although such analysis had already been conducted. The $t$-test that was conducted showed no significant difference in age between the male and female groups.

Additionally, you commented on the possibility that the complication of dementia associated with aging may have been overlooked. When patients were recruited for this study, we employed no tool or similar strategy to diagnose dementia. However, we excluded patients with dementia as much as possible from this study by interviewing the patients during the doctor's examination, and conversing with key persons who know individual patients (eg, family members, blood relatives, and others living with the patient) about the presence/absence of signs of dementia, forgetfulness, etc. In this way, we took sufficient care to avoid problems related to the entry of patients into the study.

\section{Disclosure}

The author reports no conflicts of interest in this communication.

Dove Medical Press encourages responsible, free and frank academic debate. The content of the Clinical Interventions in Aging 'letters to the editor' section does not necessarily represent the views of Dove Medical Press, its officers, agents, employees, related entities or the Clinical Interventions in Aging editors. While all reasonable steps have been taken to confirm the content of each letter, Dove Medical Press accepts no liability in respect of the content of any letter, nor is it responsible for the content and accuracy of any letter to the editor.

\section{Publish your work in this journal}

Clinical Interventions in Aging is an international, peer-reviewed journal focusing on evidence-based reports on the value or lack thereof of treatments intended to prevent or delay the onset of maladaptive correlates of aging in human beings. This journal is indexed on PubMed Central, MedLine,
CAS, Scopus and the Elsevier Bibliographic databases. The manuscript management system is completely online and includes a very quick and fair peer-review system, which is all easy to use. Visit http://www.dovepress. com/testimonials.php to read real quotes from published authors. 